\title{
Preliminary Investigation of Precious and Base Metals Mineralization on Basement Rocks of Geresse Area, Southern Ethiopia
}

\author{
Gosaye Berhanu \\ Department of Geology in Arba Minch University \\ Arba Minch, Ethiopia
}

\author{
Tamene Tadele, Gebru Hadush, Muluken Fanta, \\ Agenegnehu Borko \\ Department of Geology in Arba Minch University \\ Arba Minch, Ethiopia
}

\begin{abstract}
The present study has been conducted to access precious and base metals mineralization in Gamo district, southern Ethiopia. Lithological and structural map of the study area is generated at the scale of 1:50,000. Forty-nine stream sediment samples were collected from sets of first and second order of streams and analysis of precious and base metals mineralization $(\mathrm{Cu}, \mathrm{Pb}, \mathrm{Zn}$, etc) conducted using Atomic Absorption Spectrometry. The lithologies exposed in the area are Pegmatite, Granitic gneiss, Amphibole gneiss, Amphibolite, Schist and rhyolite. The study area is characterized by ductile and brittle geological structures such as foliation, folds, joints, dikes, veins and vein lets. Except copper, all precious and base metals contents are below the threshold value and they are insignificantly mineralized in the study area. Copper has high mineralization on the study area with a threshold value of $656.9 \mathrm{ppm}$ which further indicates copper mineralization in the study area.
\end{abstract}

Key words: Mineralization, sediment, base metals, rock

\section{INTRODUCTION}

Mineral resources play a vital role in the economic development of a country. Ethiopia is endowed with a variety of mineral resources which can raise economy of the country. This country is enriched with Precambrian to Cenozoic rocks which fall under three major categories, including sedimentary, igneous and metamorphic rocks. A quarter of the country is underlain by Precambrian metamorphic terrains. The Precambrian rocks of Ethiopia contain a wide variety of sedimentary, volcanic and intrusive rocks which have been subjected to varying degrees of metamorphism and deformation. The highest metamorphic grade of the granulite facies has been recorded in gneisses of the southern and south-western part of the country [5].

The crystalline basement rocks of Ethiopia is a particular interest because of the fact that it contains almost all known mineral commodities of the country including both metallic and industrial minerals and rocks. Geological mapping and mineral explorations done by the Ethiopian institute of Geological Survey show that metallic resources are mostly genetically linked to the tectono-thermal evolution of the various low grade metamorphic volcanosedimentary belts belonging to the upper Proterozoic 900500Ma Arabian Nubian shield terranes.

The low metamorphic grade of Precambrian basement rocks and structural features favorability has encouraged mineral exploration activities by the Ethiopia Institute of Geological Survey since 1970 and 1972 [1 and 3].

Basement rocks of low grade metamorphic rocks are considered to be the host rocks for placer gold and heavy metals in Ethiopia. Most of the known metallic mineralizations are hosted in low grade metamorphic rocks exhibiting geochemical anomalies for gold and base metals. Ethiopia is subpart of East African Orogeny containing two major metamorphic belts; including Mozambique belt extending Northward through Kenya to Ethiopia and Arabian Nubian shield propagating southward from Jerusalem to Northern Ethiopia. The study conducted by [2] indicated the occurrences of heavy minerals around, Konso, Kayle area, southern Ethiopia. The study area is dominantly covered by high grade metamorphic rocks and it is dominantly the northern extension of Mozambique belt. The main aim of this study is to carry out potential assessment on precious and base metals mineralization around, Geresse district, Southern Ethiopia.

\section{DESCRIPTION OF THE STUDY AREA \\ Location of the Study Area \\ The study area is located at southern Ethiopia, Gamo zone, Gerese district, at a distance of about $556 \mathrm{~km}$ from Addis Ababa, the capital city of Ethiopia. It is found at a distance of about $98 \mathrm{~km}$ in south east direction from Arba Minch town. Geographically, the study area is bounded between latitudes of $643000 \mathrm{~m}$ to $653000 \mathrm{~m}$ North and longitudes of $294000 \mathrm{~m}$ to $303000 \mathrm{~m}$ East (Fig.1). The total areal coverage of the study area is 73.5 square kilometers.}




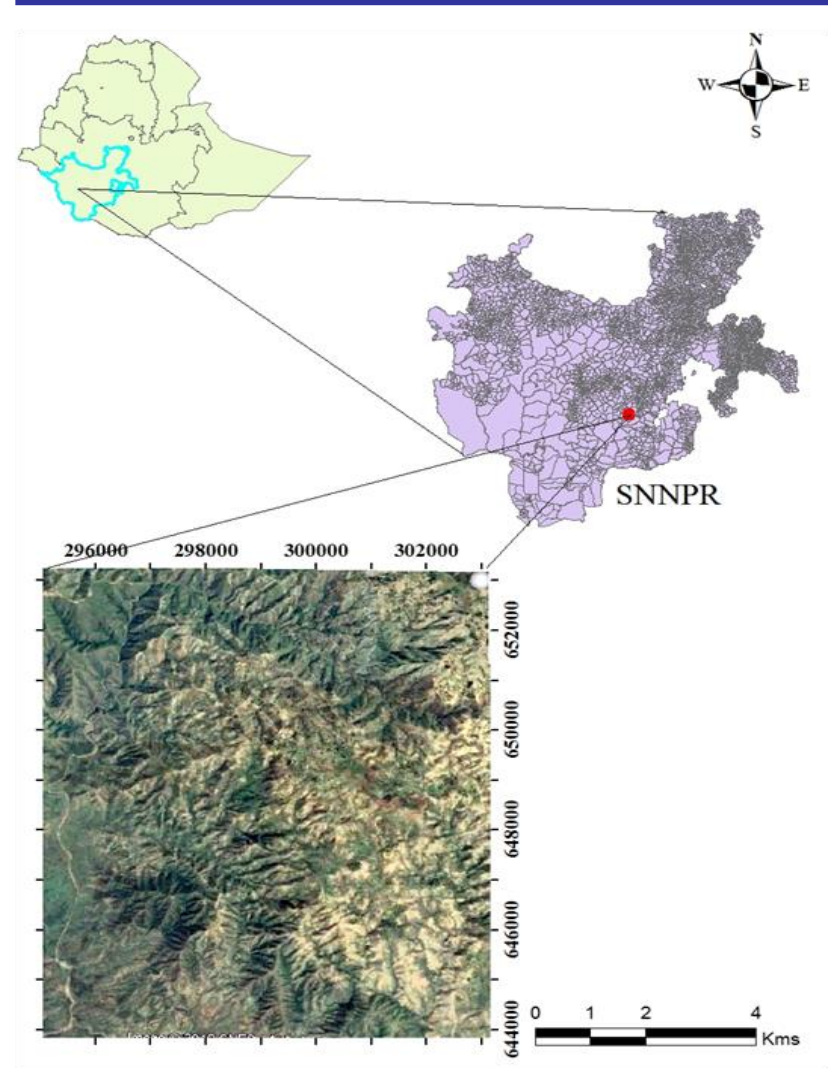

Fig.1. Location of the study area.

Physiography of the Study Area

The study area is characterized by rugged topography with intervening hills and valleys formed due to various geological processes. The elevation of the area ranges from $916 \mathrm{~m}$ to $2000 \mathrm{~m}$ above sea level and the lowest elevation was recorded at Dancha river located at the western margin of the study area (Fig.2).

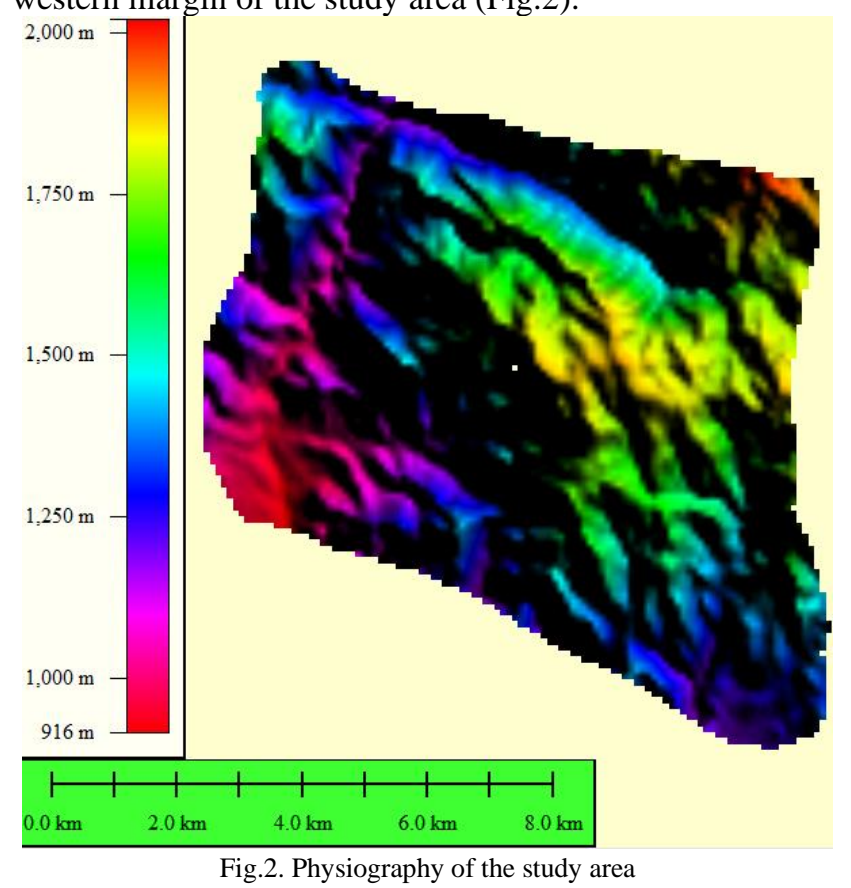

Drainage Network of the Study Area

There are three major rivers in the study area; namely, Dancha, Sobana and Boba. Dancha river runs Southward in the Western part of the study area. Sobana river runs towards North-West from South-Eastern part of the study area. Boba is one of the three major rivers in the study area which runs Southward in the Eastern part of the study area. There are numerous tributaries feeding these major rivers. The overall drainage patterns of the study area are dendritic (Fig.3).

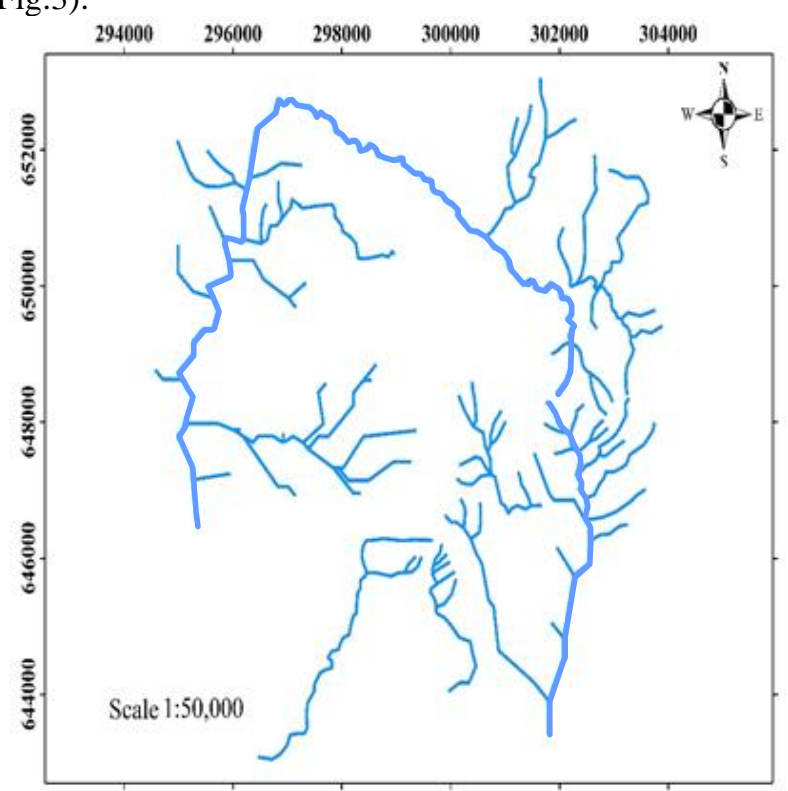

Fig.3. Drainage pattern of the study area

Stream sediment samples distribution

Forty-nine stream sediment samples were collected from the first and second order streams in order to make precious and base metals analysis.

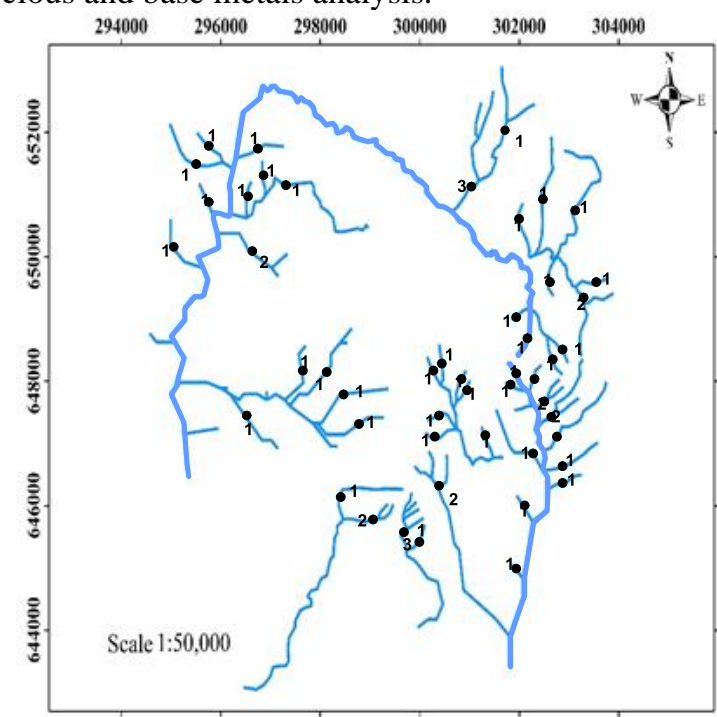

Fig.4. Stream order and sediment samples distribution map

\section{OBJECTIVE OF THE STUDY}

\section{General objective}

The main objective of this research is to study precious and base metals mineralization potential around Geresse district, southern Ethiopia.

Specific objectives

Ó Identification and recording of different lithological and structural data. 
Ó Production of geological map at the scale of 1:50,000.

Ó Identification of geochemical anomalies of precious and base metals mineralization.

Ó Generating precious and base metals distribution maps at the scale of 1:50,000.

\section{METHODOLOGY}

Various techniques of methods are used to achieve the mentioned general and specific objectives of this study. Before the field work proceeds, various activities were performed at office level. Satellite images of the study area were digitally processed using ERDAS 9.2 software. ARCGIS 10.5 software was used to delineate the boundary and drainage pattern of the study area. Global mapper is used to prepare DEM (digital elevation model) of the study area.

Different traverse lines were selected based on the possibility of geological exposures on the study area. In each traverse, many stations are taken along the traverse line at different places that helped for identifying and describing lithological units and geological structures. Geological map of the study area is produced at scale of 1 : 50,000 .

Stream sediments were collected during the second phase field work. Before departure to field, stream orders have been identified by using digital elevation model data of the study area. Based on the predetermined sample locations, enough sizes of stream sediments were collected from the first and second order streams. The point of sampling was designed to be immediately on the upstream of all confluences. Samples were collected from both the wet and dry streams.

A total of forty-nine stream sediment samples were collected to conduct gold and base metal analysis. Stream sediment samples are scooped up by hand at most sample sites but in areas with steep banks and very dry and intact places, shovel is used to pick samples to the plastic packet. All sample packets are filled and coded properly at each sample site. The stream sediment samples were then air dried for one week before submitted for analysis (Fig.5). The dried sediments were crushed by mortar and sieved by ample -80 mesh material for analysis. The prepared stream sediment samples were sent to Ezana Mining Development Plc (Analytical Laboratory) for precious and base metals analysis. Base metals content is analyzed by using inductively coupled plasma mass spectrometry (annex.1).

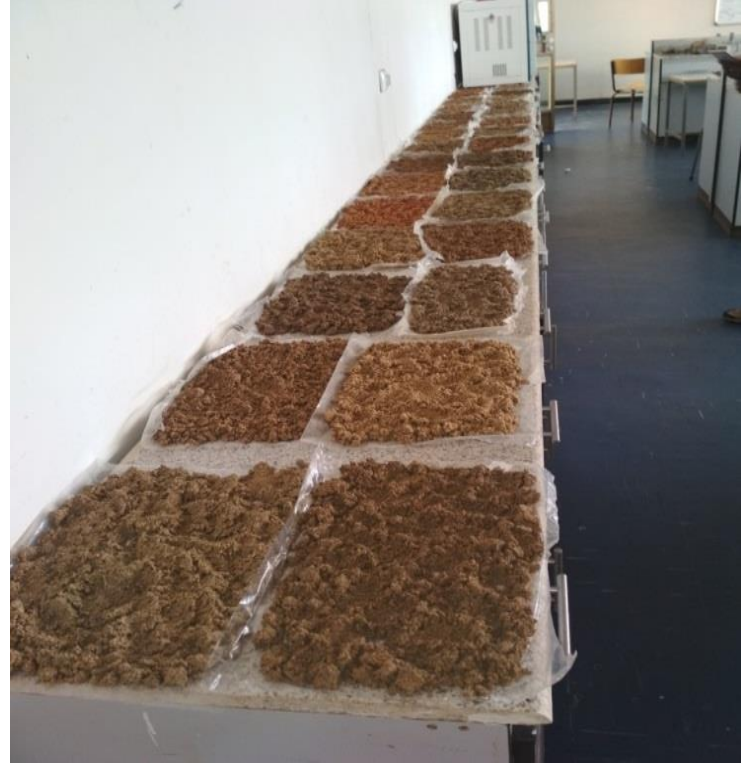

Fig.5. Stream sediment samples air dried for analysis.

\section{RESULT AND DISCUSSION}

Geology of the study area

The study area is characterized by high grade metamorphic rocks and numerous pegmatitic intrusions with small and unmappable quartz and pegmatite veins. The study area has different types of lithological units which are exposed along river cut, hill side and road cut. The lithologies exposed in the study area are Pegmatite, Granitic gneiss, Amphibole gneiss, Amphibolite, Schist and Rhyolite (Fig.17). All lithologies are mappable in a given scale except schist which covers small part from the study area. Rhyolite

This rock unit has peculiar feature of flow banding. It appears pink in color and fine-grained in texture. Development of yellow color from the outcrop due to effects of wethering shows limonitization (Fig.6).

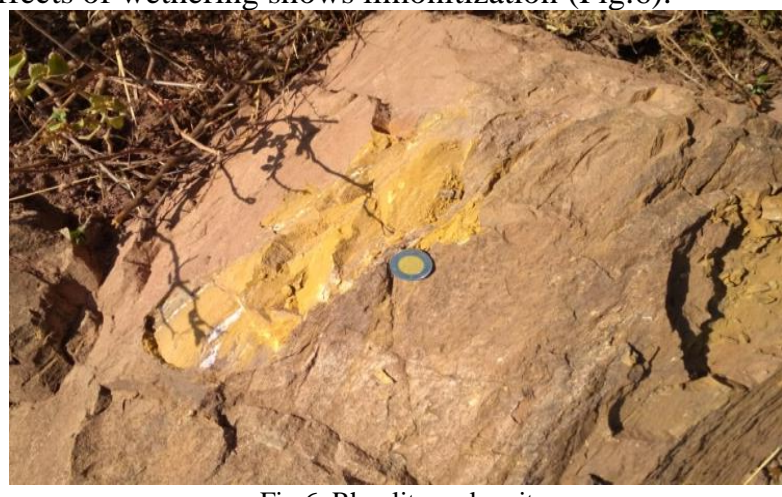

Fig.6. Rhyolite rock unit

Pegmatite

The rock unit is very coarse-grained and granitic in composition. This unit is characterized as post-tectonic intrusion where it shows clear cross-cutting of the earlier formed surrounding metamorphic rocks and itself has no deformation history at all. Typically formed during the final stage of magma chamber crystallization when high water content solution allows rapid crystal growth. Pegmatite of the study area is rich in alkali feldspar, muscovite and quartz with minor amounts of biotite, aquamarine, magnetite and garnet minerals (Fig.7). 


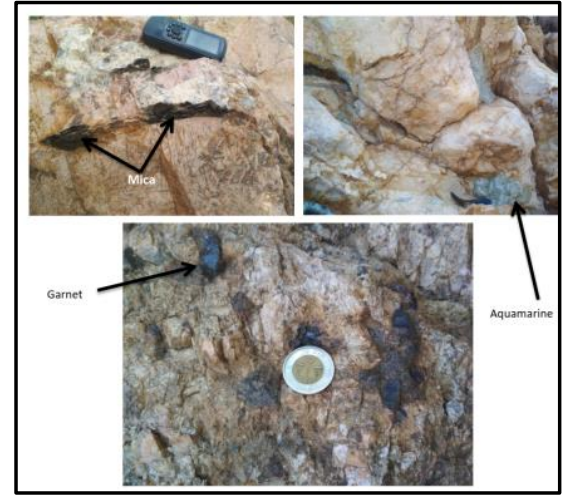

Fig.7. Pegmatite unit containing aquamarine and garnet mineral.

\section{Granitic gneiss}

This rock unit shows gneissosity due to subsequent segregation of lighter (felsic) and darker (mafic) minerals. The outcrop is exposed mainly at lowest elevation levels along major river flow directions. It associated with lineated/boudinage rocks and small-scale Ptygmatic folds.

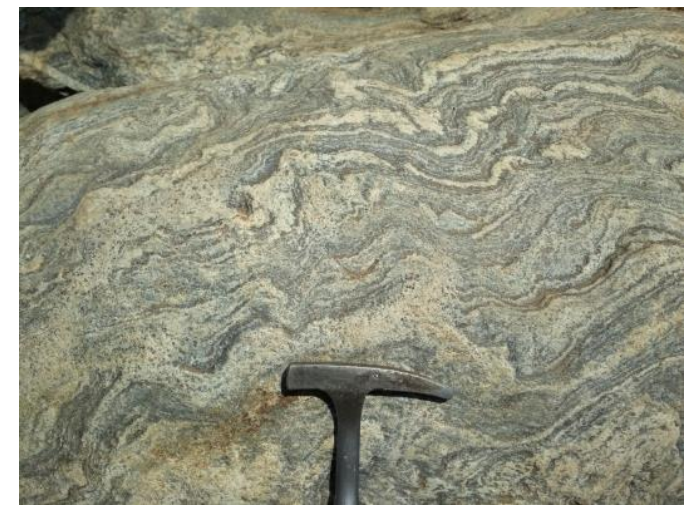

Fig.8. Granitic gneiss showing poly-phase folding

\section{Amphibole Gneiss}

It displays distinct foliation, representing alternating layers composed of amphibole minerals, with felsic minerals (quartz, muscovite and k-feldspar). It is exposed along the river cut and around hill side. From its coarse grain size, it can be considered as high grade metamorphic rock. The foliation trend of this rock unit is NNE to NNW which is almost the same with the trend of the East African Orogeny. First and second generations of quartz veins are clearly visible cross-cutting each other which further confirms histories of multiple deformation phases in the study area (F ig.9).

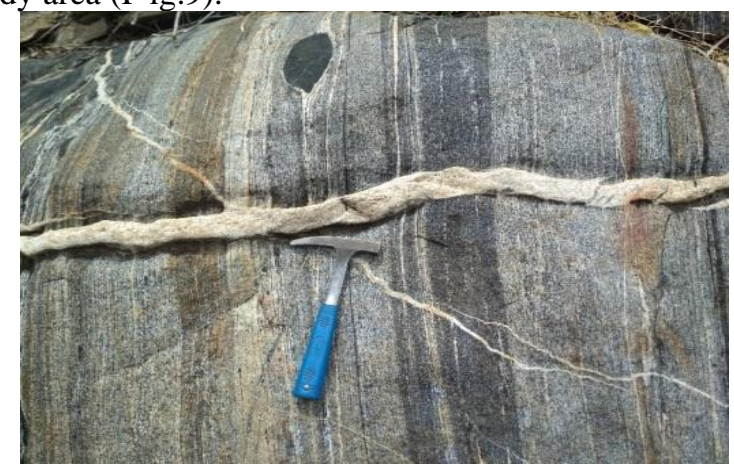

Fig.9. Amphibole gneiss with augen structure and cross cut by quartz veins

\section{Amphibolite}

It is one of a non-foliated metamorphic rock exposed along road cut and covers small part of the study area. It is found associated with amphibole gneiss and granitic gneiss. It is massive and dark color due to its abundant darker amphibole minerals (Fig.10). This rock unit shows effects of wethering where it developed chlorite minerals (chloritization) due to hydration reaction and it is indicators for retrograde metamorphism (Fig.11).

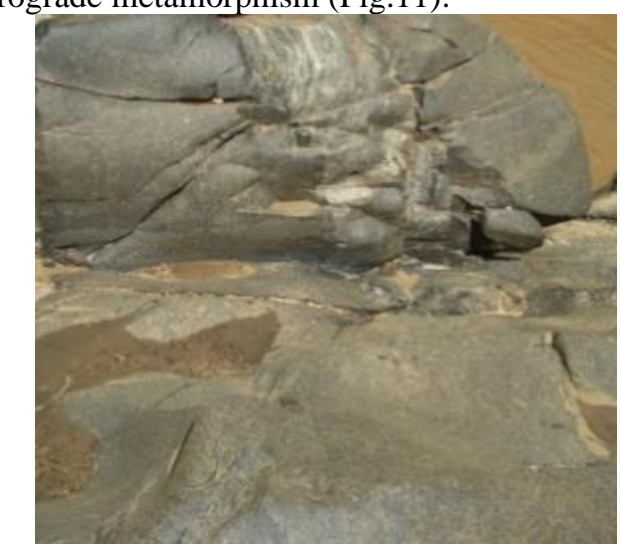

Fig.10.Amphibolite unit

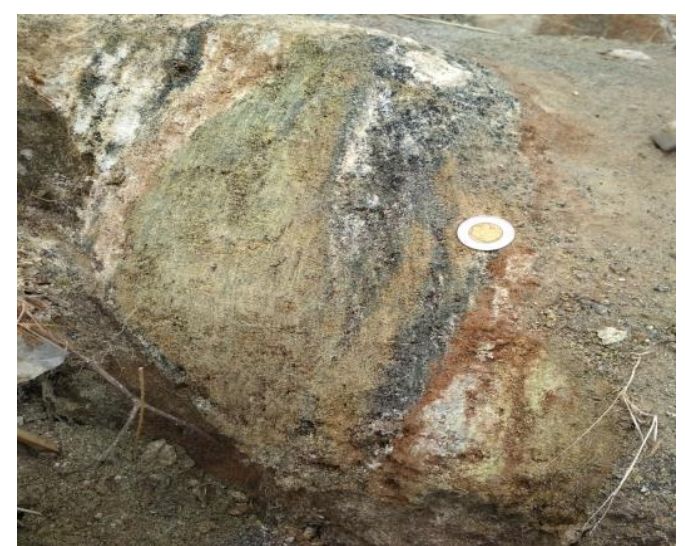

Fig.11. Chloritization alterations on amphibolite unit

\section{Geological Structures}

There are both brittle and ductile geological structures observed in the study area. Tectonic processes are responsible for the many discontinuity planes and they resulted in different geologic macrostructures. Foliation, fold, joint, dike, veins and veinlets are the major deformational structures observed in study area. There are ductile shear sense indicators in the study area which are characterized by showing different vergence directions. These vergence directions are indications for different deformation phases which show east and west vergence direction in the area and this is resulted from sinistral (leftlateral) and dextral (right lateral) shearing effects.

Brittle geological structures

Joints

Joints are fractures formed without any significant displacement and observed in amphibole gneiss rock and pegmatite dykes of the study area and resulted during brittle deformation phase. There are different generations of joints in different parts of the study area which are parallel or oblique to foliation. 


\section{Dikes}

These geological structures found in the study area are tabular in shape and discordant in orientation with the country rock. Some are mafic in composition (basalt dike) and others are felsic (pegmatite dikes) formed when magma intrudes to the country rock. Their average thickness ranges from $50 \mathrm{~cm}$ to $8 \mathrm{~m}$ and have variable length.

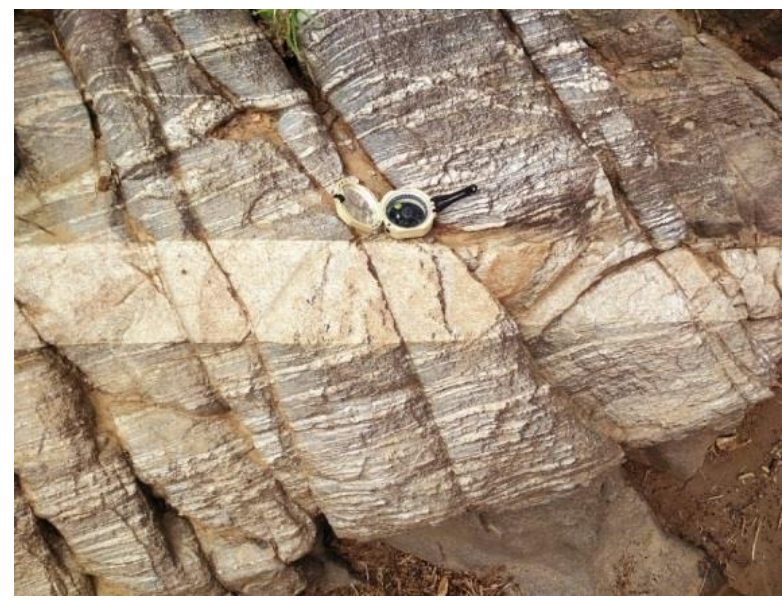

Fig.12. Non-systematic joints on amphibole gneiss

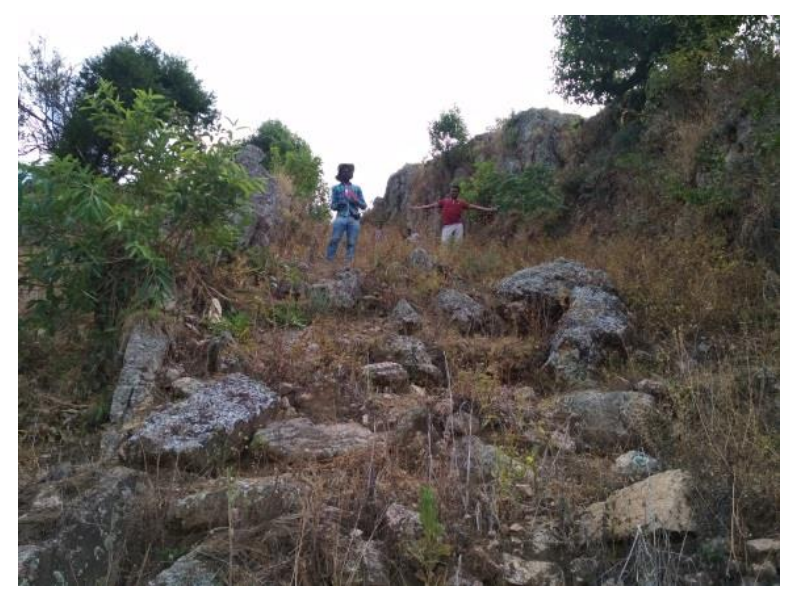

Fig.13. Two parallel pegmatite dykes on amphibole gneiss.

\section{Ductile geological structures}

\section{Boudinage}

Boudins form when lengthening affects a layered rock formation involving competent felsic layers (granite/pegmatite) boudinaged within a less competent, easily deformable, host rock (amphibole gneiss). Upon stretching, the competent layer lengthening via heterogeneous thinning leading to the development of pinch and swell structures (Fig.14). Thinning and necking in the stronger layers often initiates via the development of extensional fractures. Extension proceeds without rotation and evolves with symmetric boudinages.

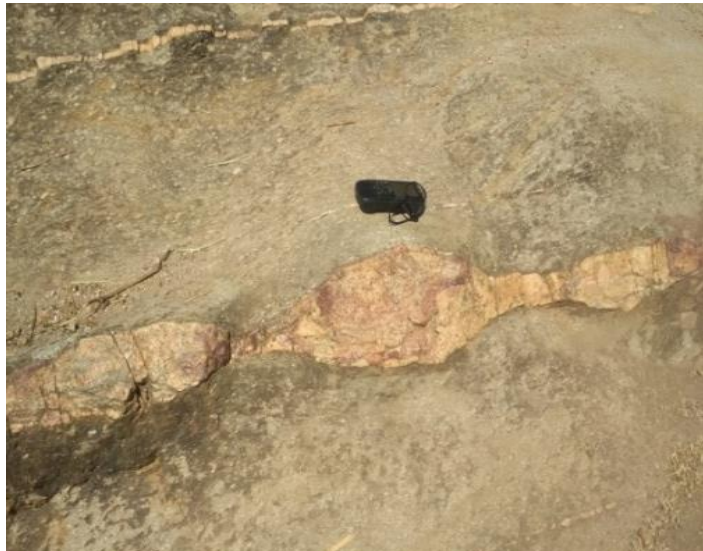

Fig.14. Boudinage structure developed on amphibole gneiss

There are several small-scale ductile shear zone indicator features in the study area which are used to determine the sense of shear. These shear sense indicators are asymmetric folds and mica fish and shows both sinistral (left-lateral) and dextral (right-lateral) sense of shearing (Fig.15).

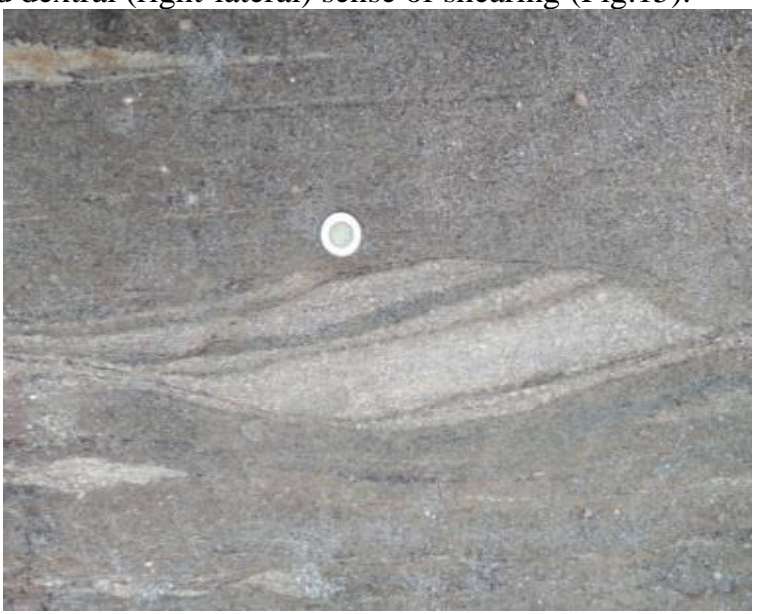

Fig.15. Mica-fish structure on amphibole gneiss

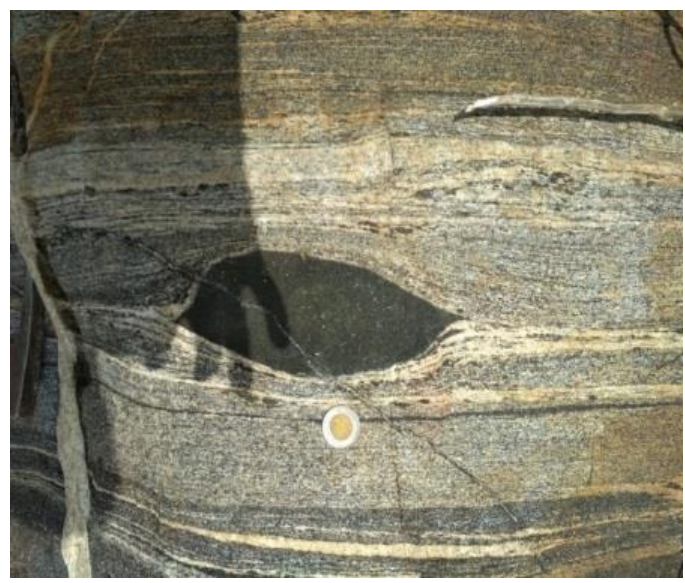

Fig.16.Augen gneiss 


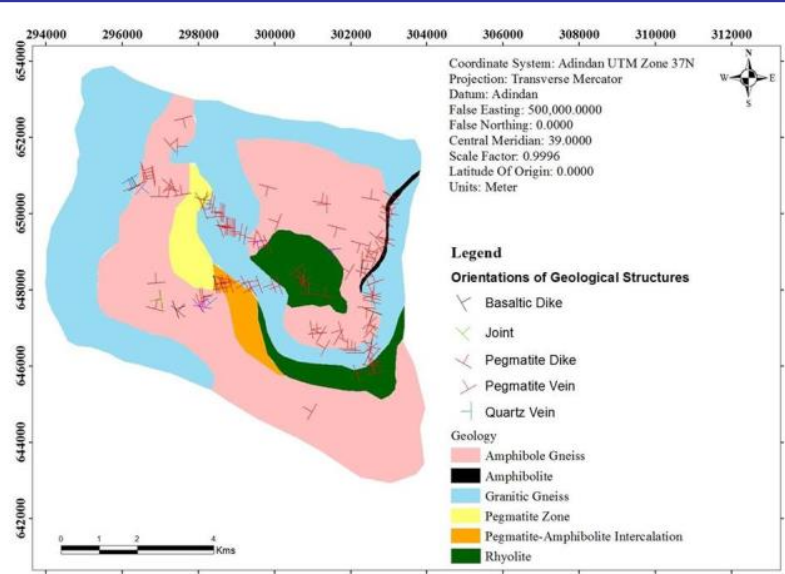

Fig.17. Geological map of the study area

\section{Stream sediment samples analysis}

Forty nine stream sediment samples collected from the study area are air dried and analyzed for precious and base metals concentrations using inductively coupled plasma mass spectrometry (Table. I).

The first task in looking at a set of geochemical analytical results from the study area is to select the anomalous values which might be indicative of a mineralized source. The level above which values may be considered anomalous is known as the threshold has been mathematically defined as the mean value plus twice standard deviations.

Threshold $=$ Mean value $+2 *$ Standard Deviation

TABLE I. STREAM SEDIMENT SAMPLES ANALYTICAL RESULTS IN PPM

\begin{tabular}{|c|c|c|c|c|c|c|c|c|}
\hline Sample ID & Easting & Northing & Elevation & Au & Ag & $\mathbf{P b}$ & $\mathbf{C u}$ & Zn \\
\hline KSS-1 & 302172 & 648489 & 1750 & $<0.02$ & $<0.2$ & 11 & 27 & 27 \\
\hline KSS-2 & 302135 & 648436 & 1700 & $<0.02$ & 0.4 & 11 & 20 & 36 \\
\hline KSS-3 & 302261 & 648269 & 1663 & $<0.02$ & 0.2 & 10 & 19 & 26 \\
\hline KSS-4 & 302243 & 648266 & 1660 & $<0.02$ & 0.3 & 10 & 18 & 27 \\
\hline KSS-5 & 302397 & 648215 & 1632 & $<0.02$ & 0.2 & 6 & 19 & 17 \\
\hline KSS-6 & 302413 & 648011 & 1624 & $<0.02$ & 0.2 & 8 & 10 & 18 \\
\hline KSS-7 & 302638 & 647690 & 1559 & $<0.02$ & 0.3 & 6 & 20 & 25 \\
\hline KSS-8 & 302706 & 647271 & 1512 & $<0.02$ & 0.4 & 7 & 36 & 37 \\
\hline KSS-9 & 302695 & 646992 & 1521 & $<0.02$ & 0.2 & 6 & 28 & 25 \\
\hline KSS-10 & 302517 & 646834 & 1461 & $<0.02$ & 0.3 & 9 & 23 & 31 \\
\hline KSS-11 & 302744 & 646666 & 1475 & $<0.02$ & 0.2 & 7 & 26 & 32 \\
\hline KSS-12 & 302728 & 646287 & 1419 & $<0.02$ & $<0.2$ & 2 & 7 & 10 \\
\hline KSS-13 & 301378 & 647165 & 1601 & $<0.02$ & $<0.2$ & 6 & 1 & 13 \\
\hline KSS-14 & 297095 & 651246 & 1265 & $<0.02$ & $<0.2$ & 2 & 21 & 20 \\
\hline KSS-15 & 297010 & 651348 & 1242 & $<0.02$ & 0.4 & 8 & 19 & 26 \\
\hline KSS-16 & 296898 & 651232 & 1225 & $<0.02$ & $<0.02$ & 6 & 24 & 30 \\
\hline KSS-17 & 296712 & 651350 & 1247 & $<0.02$ & $<0.02$ & 2 & 4 & 7 \\
\hline KSS-18 & 296694 & 651804 & 1275 & $<0.02$ & 0.3 & 5 & 31 & 23 \\
\hline KSS-19 & 296681 & 651914 & 1213 & $<0.02$ & 0.3 & 7 & 28 & 24 \\
\hline KSS-20 & 296392 & 651731 & 1109 & $<0.02$ & 0.2 & 5 & 21 & 21 \\
\hline KSS-21 & 296443 & 651060 & 1100 & $<0.02$ & $<0.2$ & 3 & 10 & 16 \\
\hline KSS-22 & 296153 & 651022 & 1069 & $<0.02$ & 0.2 & 5 & 12 & 14 \\
\hline KSS-23 & 301374 & 648189 & 1705 & $<0.02$ & $<0.02$ & 4 & 4 & 12 \\
\hline KSS-24 & 300928 & 648231 & 1732 & $<0.02$ & $<0.02$ & 6 & 6 & 32 \\
\hline KSS-25 & 300807 & 648233 & 1700 & $<0.02$ & 0.3 & 8 & 7 & 50 \\
\hline KSS-26 & 300692 & 647991 & 1696 & $<0.02$ & 0.2 & 6 & 5 & 41 \\
\hline KSS-27 & 300572 & 647828 & 1690 & $<0.02$ & 0.3 & 12 & 7 & 33 \\
\hline KSS-28 & 300392 & 647237 & 1684 & $<0.02$ & $<0.2$ & 7 & 3 & 23 \\
\hline KSS-29 & 300276 & 647027 & 1628 & $<0.02$ & $<0.2$ & 4 & 1 & 30 \\
\hline KSS-30 & 300337 & 646589 & 1560 & $<0.02$ & 0.3 & 10 & 19 & 40 \\
\hline KSS-31 & 300388 & 646445 & 1555 & $<0.02$ & $<0.2$ & 5 & 6 & 22 \\
\hline KSS-32 & 300196 & 645845 & 1475 & $<0.02$ & 0.3 & 7 & 13 & 48 \\
\hline KSS-33 & 299843 & 645827 & 1430 & $<0.02$ & $<0.2$ & 6 & 8 & 19 \\
\hline KSS-34 & 299400 & 646092 & 1372 & $<0.02$ & $<0.2$ & 4 & 4 & 63 \\
\hline KSS-35 & 299373 & 646185 & 1356 & $<0.02$ & 0.2 & 6 & 8 & 32 \\
\hline KSS-36 & 299374 & 646216 & 1346 & $<0.02$ & $<0.2$ & 6 & 15 & 64 \\
\hline KSS-37 & 302741 & 649107 & 1755 & $<0.02$ & $<0.2$ & 4 & 7 & 16 \\
\hline KSS-38 & 302746 & 649195 & 1754 & $<0.02$ & $<0.2$ & 5 & 14 & 19 \\
\hline KSS-39 & 302863 & 649446 & 1794 & $<0.02$ & 0.3 & 9 & 33 & 33 \\
\hline KSS-40 & 302657 & 649580 & 1766 & $<0.02$ & 0.4 & 10 & 20 & 28 \\
\hline KSS-41 & 302341 & 649588 & 1720 & $<0.02$ & 0.3 & 16 & 52 & 62 \\
\hline KSS-42 & 302521 & 649877 & 1762 & $<0.02$ & 0.2 & 7 & 21 & 25 \\
\hline KSS-43 & 302552 & 650000 & 1759 & $<0.02$ & $<0.2$ & 11 & 23 & 26 \\
\hline KSS-44 & 302989 & 650306 & 1722 & $<0.02$ & 0.3 & 9 & 15 & 22 \\
\hline KSS-45 & 303110 & 650227 & 1741 & $<0.02$ & 0.2 & 11 & 34 & 39 \\
\hline KSS-46 & 303146 & 650290 & 1740 & 0.02 & 0.4 & 6 & 15 & 22 \\
\hline KSS-47 & 303103 & 650556 & 1741 & $<0.02$ & 0.5 & 11 & 38 & 35 \\
\hline KSS-48 & 302623 & 650726 & 1744 & $<0.02$ & $<0.2$ & 6 & 15 & 25 \\
\hline KSS-49 & 302563 & 650673 & 1751 & $<0.02$ & $<0.2$ & 11 & 9 & 16 \\
\hline
\end{tabular}

Abbreviation KSS (Stands for Ketele stream sediment sample) 
TABLE. II. THRESH HOLD VALUES OF SOME PRECIOUS AND BASE METAL ELEMENTS.

\begin{tabular}{|c|c|c|c|c|c|c|c|c|}
\hline \multicolumn{3}{|c|}{ Au } & \multicolumn{3}{|c|}{ Ag } & \multicolumn{3}{|c|}{$\mathbf{C u}$} \\
\hline Mean & SD & thresh hold & Mean & SD & thresh hold & Mean & SD & thresh $\mathrm{h}$ \\
\hline 0.02 & 0.29 & 0.6 & 0.35 & 0.6 & 1.55 & 16.9 & 320 & 656.9 \\
\hline & & \multicolumn{3}{|c|}{$\mathrm{Zn}$} & \multicolumn{4}{|c|}{$\mathbf{P b}$} \\
\hline & & Mean & SD & thresh hold & Mean & SD & \multicolumn{2}{|c|}{ thresh hold } \\
\hline & & 28.2 & 11 & 50.2 & 7.12 & 12 & 31.12 & \\
\hline
\end{tabular}

Gold

Based on the analytical result, gold is below detection limit $(<0.02 \mathrm{ppm})$ for all of the analyzed samples except one sample which has $0.02 \mathrm{ppm}$ of $\mathrm{Au}$. Stream sediment samples can have normal gold concentration ranges from $0.01-0.05 \mathrm{ppm}$ values [4]. Concentration value greater than $0.1 \mathrm{ppm}$ indicates gold mineralization but all analytical results are below detection limit that is less than $0.02 \mathrm{ppm}$ except one sample KSS-46 which has $0.02 \mathrm{ppm}$ that is still below the threshold value. Therefore, based on the analytical results, the area has insignificant gold mineralization.

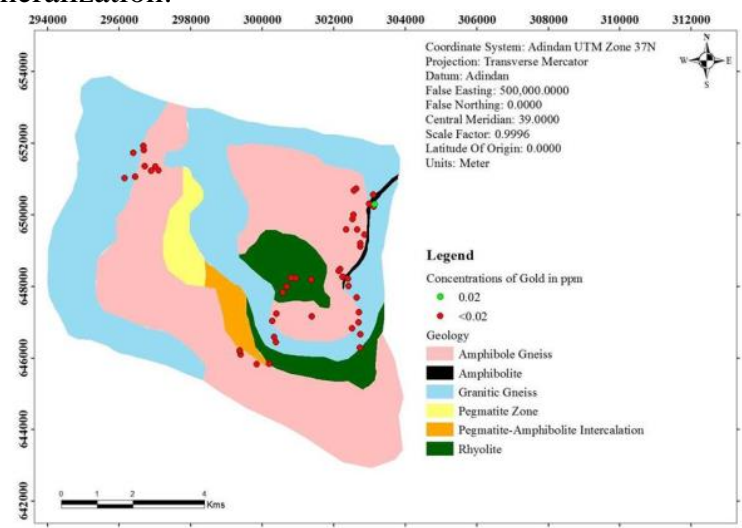

Fig.19. A map showing concentration of gold in stream sediment samples

\section{Silver}

Silver has maximum concentration value of $0.5 \mathrm{ppm}$ for Sample KSS-47 and an average concentration for the analyzed samples is 0.29ppm. KSS-46, KSS-2, KSS-8, KSS-15, KSS-40 and KSS-46 have 0.4ppm silver concentrations. Stream sediment samples having silver concentration values greater than $0.5 \mathrm{ppm}$ may indicate mineralization [4]. Based on the above result all the analyzed samples are below the level of mineralization for silver.

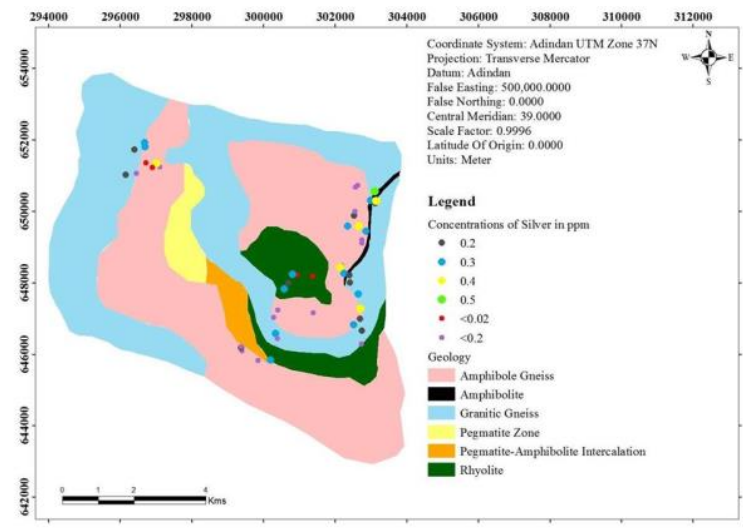

Fig.20. A map showing concentration of silver in stream sediment samples.

\section{Copper}

Copper concentration ranges from 1-52ppm and an average grade of copper values is $16.86 \mathrm{ppm}$. All of the analyzed stream sediment samples have a threshold value of 656.9 which further indicates copper mineralization in the study area.

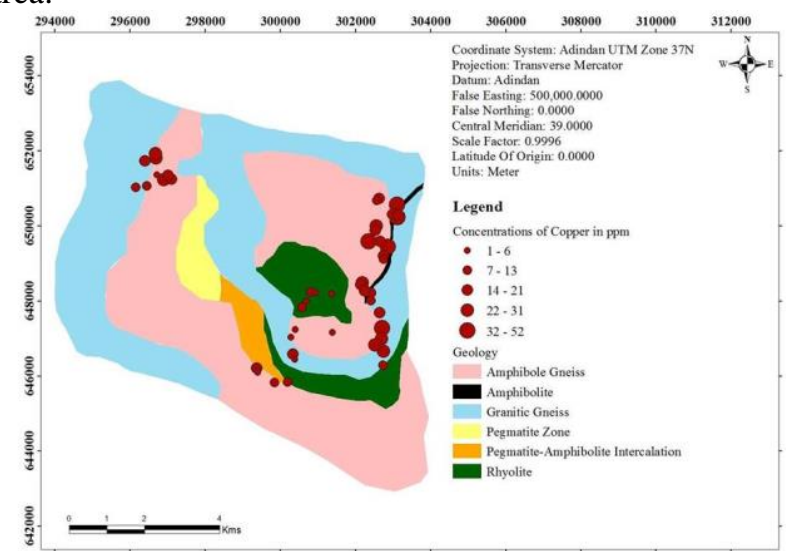

Fig.21. A map showing concentration of copper in stream sediment samples.

Zinc

Zinc concentration ranges from 7-64ppm and an average concentration is $28.2 \mathrm{ppm}$. Sample KSS-36 has maximum zinc concentration 64ppm while samples KSS-34 and KSS41 have 63 and $62 \mathrm{ppm}$ concentration values respectively. The normal zinc concentration ranges for stream sediment samples is 10-200 ppm [4], but samples having concentration values greater than $200 \mathrm{ppm}$ may indicate mineralization. According to the analytical result zinc concentration are below the threshold value and are nonmineralized.

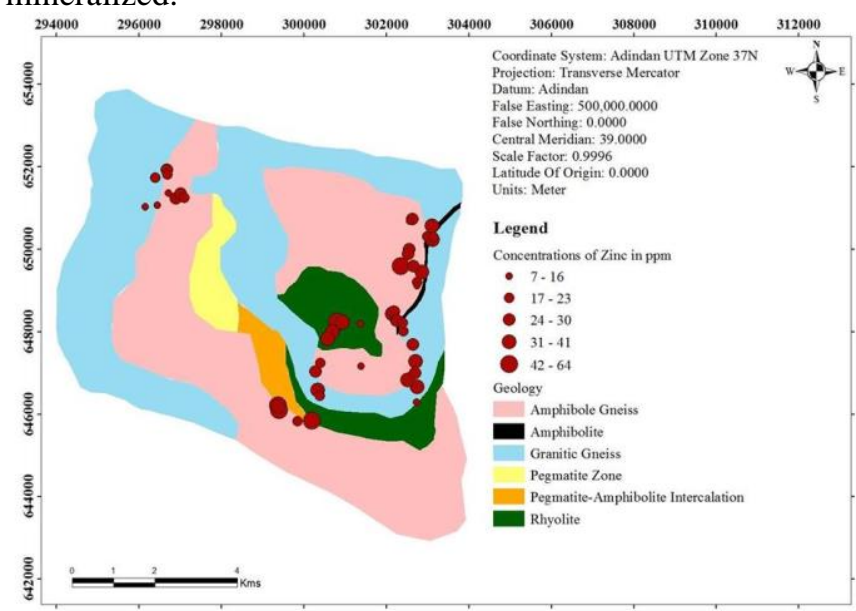

Fig.22.A map showing concentration of zinc in stream sediment samples

Lead

Lead concentration ranges from 2-16ppm and an average concentration for the analyzed samples is $7.12 \mathrm{ppm}$. Sample KSS-41 has maximum zinc concentration of $16 \mathrm{ppm}$. The 
normal standard of lead concentration to be found in stream sediment samples is 5-50 ppm [4]. Lead values greater than $100 \mathrm{ppm}$ may indicate $\mathrm{Pb}$ mineralization. Based on the above explained concentration ranges, all of the analyzed have below the threshold value and they are nonmineralized.

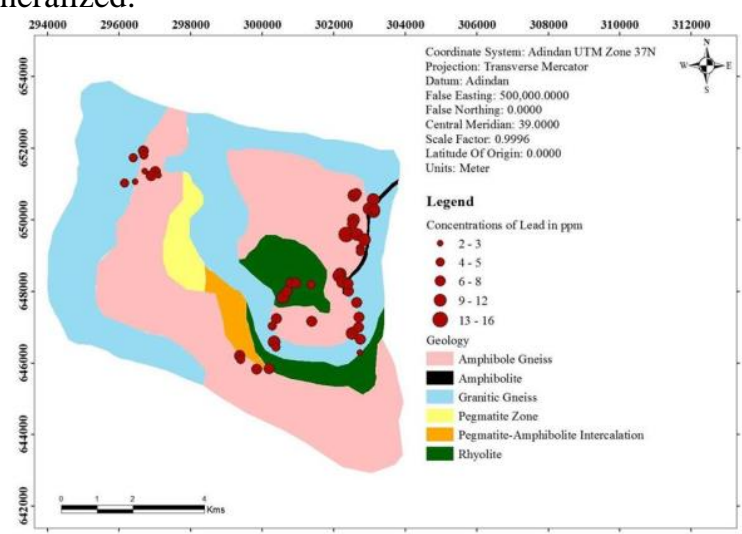

Fig.23. A map showing concentration of lead in stream sediment samples.

\section{CONCLUSION}

The present study was conducted in Geresse area, southern Ethiopia, which is part of the East African Orogeny (EAO) and an extension of Mozambique belt. The rock units of the study area are Pegmatite, Granitic gneiss, Amphibole gneiss, Amphibolite, Schist and Rhyolite.

The study area is affected by different episodes of events like: granitic intrusion, metamorphism, folding, fracture filling (veins and veinlet's formation) and distortion of veins by shearing. Three deformation phases are recognized from the study area which include development of gneissosity (D1), folding of gneissosity (D2), east and west shearing (D3).

For most of the samples, precious and base metals contents are below the threshold value and they are insignificantly mineralized in the study area.

Copper has high mineralization on the study area with a threshold value of $656.9 \mathrm{ppm}$ which is much more than the expected standard of copper concentration on stream sediments (Table.II).
Generally, copper shows relatively good concentration in amphibole gneiss outcrops that is exposed at the NorthEastern part of the study area implying that this lithology is the possible host rock for copper mineralization.

\section{ACKNOWLEDGMENT}

First of all, would like to give our sincere gratitude to southern nations, nationalities and people's regional state mines and energy agency for providing an opportunity to conduct the study. Secondly, our deepest gratitude goes to Arba Minch University, University-Industrial linkage and Technology transfer directorate office for their follow up, providing transportation and tireless support during the project work. Lastly, we would like to thank Arba Minch University, Department of Geology for giving different laboratory materials for the field work.

\section{REFERENCE}

[1] Abraham, A., Hassen, N., Yemane, T., Genzebu, W., Seyid, G.,Mehari, K., Alemu, T., The geological evolution of the Proterozoic of southern Ethiopia, Abstract. In: 29th International Geological Congress 2, Kyoto, Japan, 1992, 13p.

[2] Bekele Ayele, 2017. Geological Investigation and the Occurrence of Heavy Minerals around Kayle Area, Konso Regional State, Southern Ethiopia.

[3] Jelene, A. Mineral occurrences of Ethiopia. Ministry of Mines, Addis Ababa, 1966. 720p.

[4] Reedman.J.H. 1979. Techniques in Mineral Exploration, Noranda Exploration Company Ltd, Winnipeg, Canada.

[5] Solomon Tadesse, Jean-Pierre Milesi, Yves Deschamps, 2003. Geology and mineral potential of Ethiopia: a note on geology and mineral map of Ethiopia. 
ANNEX.1. CERTIFICATE OF LABORATORY ANALYSIS

$\begin{gathered}\text { Ezana Mining Development PIc } \\ \text { Analytical Laboratory } \\ \text { Mekelle, Ethiopia } \\ \text { Tel.: }+2513444408779,401358, \\ \text { Fax: }+251344405453,\end{gathered}$
P. O. BOX: 788, e-mail: ezanalabiethionet.et

\section{CERTIFICATE OF ANALYSIS}

CLIENT NAME: Arbaminch University

ADDRESS: Arbaminch

ATT: Ato Asefa Weldu

TEL.: 0914020895

INVOICE: BEC/702/19

CLIENT REF.:

NO. SAMPLES: 49

SAMPLE TYPE: Soil

Condition of samples:Normal
LAB JOB NO. EAL-19A0640

SAMPLES RECEIVED:09/07/2019

ANALYSIS INSTRUCTIONS RECEIVED :09/07/2019

DATE OF REPORT: 18/9/2019

STATUS OF REPORT: Final

ANALYSIS COMPLETE: 19/9/2019

Nominated Representative

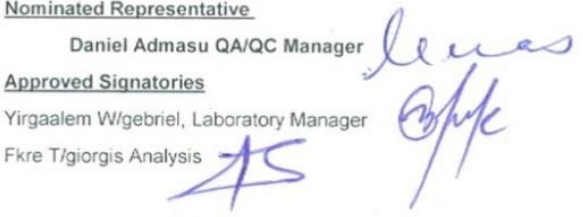

This report relates specifically to the sample(s) tested in so far as that the sample(s) is truly representative of the sample source as supplied. All pages of this report have been checked and approved for release. Notes/Comments:

\begin{tabular}{ccccccccc}
\hline No & Sample idents & $\mathrm{Au}$ & $\mathrm{Ag}$ & $\mathrm{Pb}$ & $\mathrm{Cu}$ & $\mathrm{Zn}$ & $\mathrm{Co}$ & $\mathrm{Ni}$ \\
1 & KSS-1 & $<0.02$ & $<0.2$ & 11 & 27 & 27 & 14 & 22 \\
2 & KSS-2 & $<0.02$ & 0.4 & 11 & 20 & 36 & 24 & 16 \\
3 & KSS-3 & $<0.02$ & 0.2 & 10 & 19 & 26 & 14 & 12 \\
4 & KSS-4 & $<0.02$ & 0.3 & 10 & 18 & 27 & 16 & 22 \\
5 & KSS-5 & $<0.02$ & 0.2 & 6 & 19 & 17 & 7 & 14 \\
6 & KSS-6 & $<0.02$ & 0.2 & 8 & 10 & 18 & 7 & 10 \\
7 & KSS-7 & $<0.02$ & 0.3 & 6 & 20 & 25 & 8 & 8 \\
8 & KSS-8 & $<0.02$ & 0.4 & 7 & 36 & 37 & 13 & 18 \\
9 & KSS-9 & $<0.02$ & 0.2 & 6 & 28 & 25 & 9 & 19 \\
10 & KSS-10 & $<0.02$ & 0.3 & 9 & 23 & 31 & 11 & 19 \\
11 & KSS-11 & $<0.02$ & 0.2 & 7 & 26 & 32 & 11 & 36 \\
12 & KSS-12 & $<0.02$ & $<0.2$ & 2 & 7 & 10 & 3 & 10 \\
13 & KSS-13 & $<0.02$ & $<0.2$ & 6 & 1 & 13 & 4 & 4 \\
14 & KSS-14 & $<0.02$ & $<0.2$ & 2 & 21 & 20 & 6 & 8 \\
15 & KSS-15 & $<0.02$ & 0.4 & 8 & 19 & 26 & 10 & 10 \\
16 & KSS-16 & $<0.02$ & $<0.2$ & 6 & 24 & 30 & 8 & 9 \\
17 & KSS-17 & $<0.02$ & $<0.2$ & 2 & 4 & 7 & 2 & 2 \\
18 & KSS-18 & $<0.02$ & 0.3 & 5 & 31 & 23 & 9 & 13 \\
19 & KSS-19 & $<0.02$ & 0.3 & 7 & 28 & 34 & 11 & 11 \\
20 & KSS-20 & $<0.02$ & 0.2 & 5 & 21 & 21 & 7 & 8 \\
21 & KSS-21 & $<0.02$ & $<0.2$ & 3 & 10 & 16 & 4 & 5 \\
22 & KSS-22 & $<0.02$ & 0.2 & 5 & 12 & 14 & 7 & 7 \\
23 & KSS-23 & $<0.02$ & $<0.2$ & 4 & 4 & 12 & 4 & 4 \\
24 & KSS-24 & $<0.02$ & $<0.2$ & 6 & 6 & 32 & 9 & 13 \\
25 & KSS-25 & $<0.02$ & 0.3 & 8 & 7 & 50 & 14 & 15 \\
26 & KSS-26 & $<0.02$ & 0.2 & 6 & 5 & 41 & 11 & 9 \\
27 & KSS-27 & $<0.02$ & 0.3 & 12 & 7 & 33 & 13 & 13
\end{tabular}




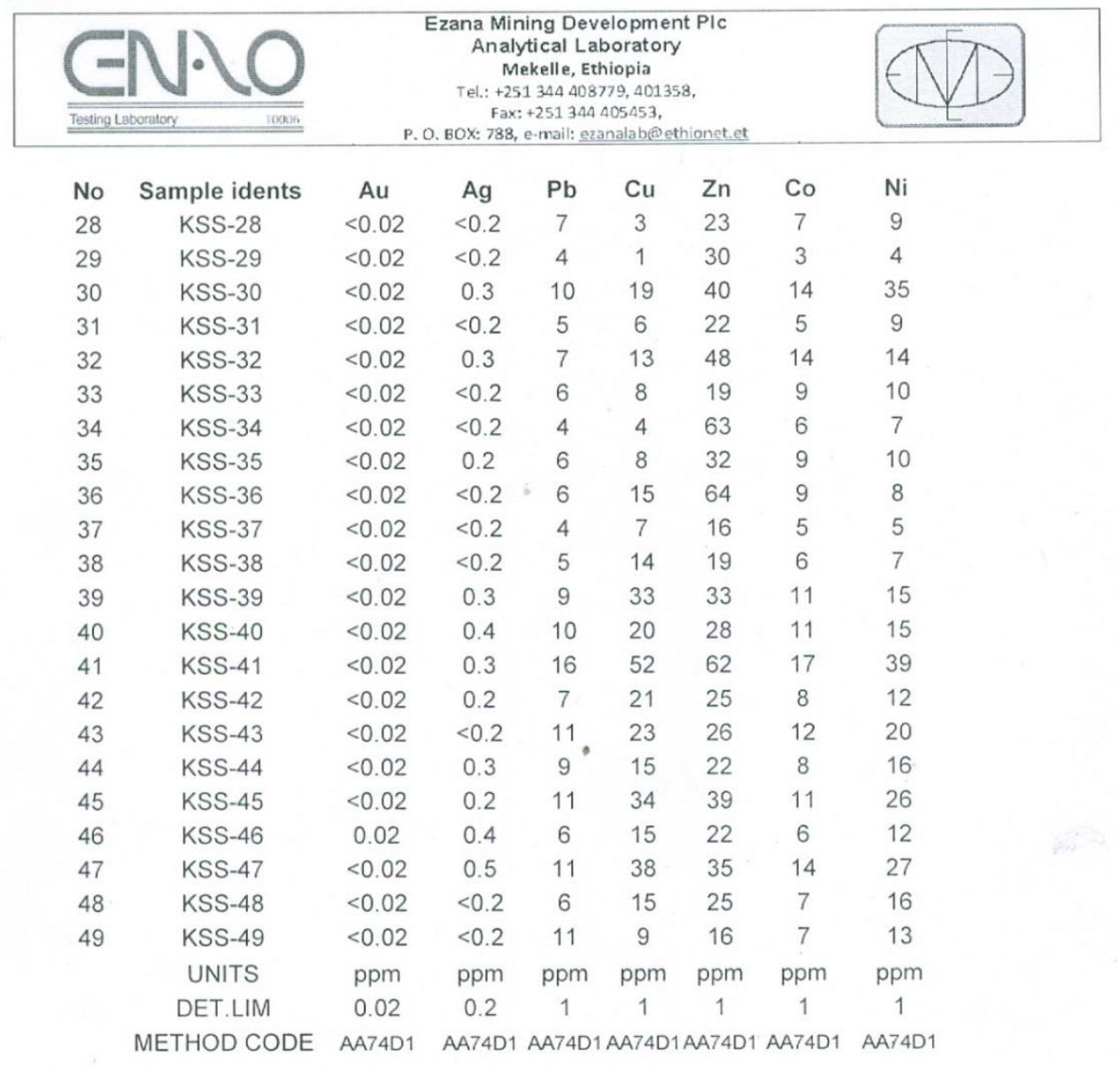

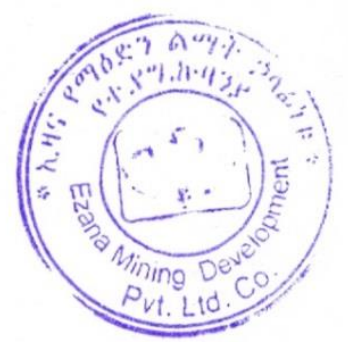

